\title{
USING DESINFECTION DEVICES IN INTENSIVE CARE UNITS
}

\author{
Azra Čamdžić́, Amela Dedeić- Ljubovićc',3,4, Kamelija Madacki-Todorovićc
}

(C) 2019 by Acta Medica Saliniana ISSN 0350-364X

DOI: $10.5457 / 525$

Azra Čamdžić

Amela Dedeić- Ljubović

Kamelija Madacki-Todorović

\begin{abstract}
Introduction: Intensiveunit microflora mainly consists of organism capableof surviving in moist media, such as gram-negative bacteria, skin-colonizing microorganisms, those with the ability to adhere to medical devices, and microorganisms resistant to conventional antibiotics. Therefore, cleansing and disinfection of intensive care units is of great importance in the prevention and control of hospital infections.

Material and Methods: The use of the device was demonstrated in the isolation room of the intensive care unit after a patient colonized with hospital bacterial strains was discharged. The first sampling was carried out immediately after the patient was discharged, the second after the standard medical cleansing of the equipment and space, and the third after the disinfection with the "SterisafePro". The analysis of the smears was performed at the OU Clinical Microbiology. Quantitative method analyses was performed according to standard operative procedure (SOP). The results of the analysis are calculated according to the formula and expressed in the values of CFU / $\mathrm{cm}^{2}$.

Results: After the patient was discharged and the area cleaned mechanically, the Acinetobacter baumanii was isolated in three samples, coagulase negative staphylococci in one, while two smears remained sterile. Acinetobacter baumanii and coagulase negative staphylococci were isolated in three samples. After using the disinfecting device, all swabs were sterile.

Conclusion: Disinfection of the hospital with the "Sterisafe"Pro" device has proved to be very successful. The advantages of using the "Sterisafe"Pro" device are that is uses no chemicals, has a low labor and usage costs, is harmless to the patients and staff, and is very easy to use.
\end{abstract}

Key words: disinfection, intensive care, sterility control.

\section{INTRODUCTION}

Intensive care microflora are predominantly microorganisms capable of surviving in humid media such as gram-negative bacteria, skin-colonizing microorganisms, and microorganisms with thecapability of adherenceto medical devices. There is an increasing concern over the escalation of antimicrobial resistance [1]. That is directly linked to hospital infections. New possibilities for the prevention of pathogen transfer are being sought, and the focus of interest is increasingly on the role of the hospital environment surfaces [2-3]. As well as cleaning and disinfection of surfaces surrounding the hospitalized patient. Although estimates of the potential of preventing hospital infections differ, it is considered that they can be prevented up to $20 \%$ in developed countries, and $40 \%$ or more in the developing countries [4]. The problem of hospital infections has been recognized as a problem of patient safety by the World Health Organization [5]. Cleaning and disinfection of surfaces in our institution is carried out according to written procedures (SOP), followed by all medical employees. These procedures should take care of preventing hospital infections, taking into account that all staff must be educated about cleaning and disinfecting surfaces and objects to perform their work efficiently.

In the event of an epidemic of the hospital infections, the frequency of cleaning and disinfection must be increased. [6]. Nevertheless, in daily praxis everyday problems in the hygiene of all surfaces, even high-risk ones, are still recognized. 
Due to lack of cleaning, many hospital surfaces remain contaminated with hospital pathogens connected to hospital infections $[2,7]$.

The aim of this paper is to show the results of the efficiency evaluation of the disinfection device "Sterisafe Pro" in Intensive care units in hospital of the tertiary level.

\section{MATERIAL AND METHODS}

The demonstration of the medical device was performed at the Anesthesia and Reanimation Clinic at the Clinical Center of the University of Sarajevo, in the isolation room after a patient colonized with hospital bacterial strains was discharged. The first sampling was carried out immediately post patient discharge, and the second after standard mechanical cleaning of the equipment and space. The third sampling of the smear was done after the disinfection cycle with the device "Sterisafe Pro". The disinfection device works by generating ozone $\left(\mathrm{O}_{3}\right)$ and scattering it together with water vapor throughout the room. There are three different cycles: short (45-9o min.), normal (75-150 min.) and long (105-180 min.), which differ in the duration of the second phase (disinfection / decontamination phase). The cycle's duration depend of the area size. In the smaller area shorter cycles is used. During the process of disinfecting at the KCUS, the longest cycle was used.

In order to start disinfection procedure properly, the area needs to be hermetically closed due to gas leakage from the room for two main reasons: ozone toxicity and reduced efficiency of the device. Before using the disinfection device, it is necessary to seal the door, windows and other openings with adhesive tape, and cover the ventilation holes and the automatic fire detectors on the ceiling with special covers that come with the device. In addition, the room should be mechanically cleansed; all organic matter that could create a biofilm should be removed. The room temperature should be between $10^{\circ} \mathrm{C}$ and $30^{\circ} \mathrm{C}$. All equipment made out of nitrile, natural rubber and other materials susceptible to the effects of ozone should be removed from the room, as ozone is a strong oxidizing agent and can be corrosive to said materials. The analysis of the taken swabs was carried out in OU Clinical Microbiology. A quantitative method of sample processing was done: the sample was inoculated into sterile buffered peptone water $\mathrm{pH}=7 \pm 0.2$ after inoculation on site and transported to the laboratory. After the vortex procedure of the basic suspension, next comes the sowing on a solid nutrient substrate of blood agar. The suspension is sifted by Surface Plate Count by 100 microliters of suspension by a sterile pipette applied to the surface of the substrate and then uniformly expanded with a sterile rod. The culture is incubated with the rest of the basic suspension in a 24- hour thermostat at $37^{\circ} \mathrm{C}$. In the case of bacterial proliferation testing, antibiotic susceptibility testing is performed to bacteria resistance test. Identification and antibiotic susceptibility testing are confirmed by an automatic method (VITEK 2 Compact system). The results of the analysis are calculated according to the formula and expressed in the values of $\mathrm{CFU} / \mathrm{cm}^{2}$

\section{RESULTS}

In our study, a total of seven swabs were taken: from the mattress, the bed frame, the console, the respirator monitor, the table of therapy, the floor and the patient heater. The sampling was carried out in three phases: immediately after the patient has been discharged, after the mechanical cleansing of the room and equipment, and after disinfection with the "Sterisafe Pro" device.

In the swabs taken after the patient was discharged and the space cleaned mechanically, Acinetobacter baumannii was isolated in three samples, Coagulase negative staphylococci in one, while two swabs remained sterile. Three samples had both Acinetobacter baumannii and Coagulase negative staphylococcus. After using the device for space disinfection all the swabs were sterile. (Table 1, Figure 1).

Table 1. Results of microbiological analysis of surface area per phase

\begin{tabular}{|l|l|l|l|l|l|}
\hline Sample type & Analysis result prior to cleansing & $\begin{array}{l}\text { Number of } \\
\text { colonies CFU/ } \\
\mathrm{cm}^{2}\end{array}$ & $\begin{array}{l}\text { Analysis result after mechanical } \\
\text { cleansing }\end{array}$ & $\begin{array}{l}\text { Number of } \\
\text { colonies } \\
\text { CFU/cm }\end{array}$ & $\begin{array}{l}\text { Analysis result } \\
\text { after “Sterisafe } \\
\text { Pro" }\end{array}$ \\
\hline $\begin{array}{l}\text { Matress } \\
\text { swab }\end{array}$ & Acinetobacter baumannii & 30 & Acinetobacter baumannii & 20 & Sterile \\
\hline Bed frame swab & Coagulase negative staphylococci & 4 & $\begin{array}{l}\text { Acinetobacter baumannii } \\
\text { Coagulase negative staphylococci }\end{array}$ & 9 & Sterile \\
\hline Console swab & Sterile & 0 & Coagulase negative staphylococci & 5 & Sterile \\
\hline $\begin{array}{l}\text { Respirator } \\
\text { monitor } \\
\text { swab }\end{array}$ & Acinetobacter baumannii & 12 & Sterile & Sterile \\
\hline $\begin{array}{l}\text { Table for therapy } \\
\text { swab }\end{array}$ & Sterile & 0 & $\begin{array}{l}\text { Acinetobacter baumannii } \\
\text { Coagulase negative staphylococci }\end{array}$ & 100 & Sterile \\
\hline Floor swab & $\begin{array}{l}\text { Acinetobacter baumannii } \\
\text { Coagulase negative staphylococci }\end{array}$ & 50 & Sterile & o & Sterile \\
\hline $\begin{array}{l}\text { Heater for } \\
\text { patient swab }\end{array}$ & Sterile & o & Coagulase negative staphylococci & 1 & Sterile \\
\hline
\end{tabular}




\section{DISCUSSION}

The environment in health facilities is constantly being contaminated with microorganisms from infected and colonized patients, staff and visitors "[6]. Surface contamination presents a major problem, especially in intensive care units where patients are in a severe health condition. The transfer of micro-organisms from "hard surfaces" to patients and from patients to the surfaces occurs mainly through the hands of health workers working or staying in that space [8]. In the room around the bed in JINJ there is a lot of patient monitoring and support equipment for that is exposed to hand contact because of their purpose [9], and the pathogens can be transferred from one to a dozen other surfaces.

Following the microbiological analysis of the swabs taken immediatelyafter thepatient has been discharged, we obtained the following results: Acinetobacter baumannii was isolated in three samples, saprophytic coca in one, while the two remaining smears remained sterile. In one sample, Acinetobacter baumannii and saprophytic coca were shown together.

Studies show that cleaning tools, cleaning and disinfection chemicals can bea source of environmental pollution. Detergent solutions and solutions of some disinfectants (e.g. quaternary ammonium salts or phenols) are contaminated immediately at the beginning of use, therefore it is important to frequently change the washing solution and to follow the cleaning sequence. The contamination of the washing solution can be reduced by using 2 buckets, so that a cleaning cloth can be soaked in one and rinsed (or washed) in the other.

Washing or disinfecting solutions should be freshly prepared every day, and the leftover solution should be immediately thrown away after cleaning. Another source of pollution during the washing process can be cleaning cloths and containers - buckets. The cloth needs to be changed each time the solution is changed, and one cloth should not be used for all categories of objects and surfaces in the room [10]. Failure to comply with the above-mentioned procedure often leads to the spread of contamination toareas that havenotpreviously been contaminated, as has been shown in our study. After mechanical cleaning, Acinetobacter baumannii was isolated from the previously microbiologically clean surfaces, and on the third surfaces saprophytic cocci were isolated in large numbers. Disinfection of space with the help of the "Sterisafe Pro" device proved to be very successful, since all surfaces after the use of the appliance remained sterile. The advantage of using the disinfection device is that chemicals are not used, the cost of labour and usage remain low, it is harmless to patients and staff and is very easy to use. When the disinfection is completed, the process is reversible, and the remaining reversible gas is converted into harmless oxygen. The room is immediately ready for entry and stay of patients and staff.The aim of the Clinical Center of the University of Sarajevo is to establish and ensure the quality of cleaning and disinfection services in the hospital area, to follow world trends, and thus prevent the transmission of pathogens over surfaces.

\section{CONCLUSION}

Disinfection of space using the "Sterisafe Pro" device proved to be very successful. The study found that the contamination of surfaces can occur during cleaning, and the use ofdisinfection devices for the intensive care area is a very important step in preventing the spread of hospital pathogens.

Each healthcare institution should establish and ensure the quality of cleaning and disinfection services, monitor global trends, and thus prevent the transmission of pathogens over surface.

\section{SAŽETAK}

Uvod: Mikrofloru jedinice intenzivne njege pretežno čine organizmi sposobni preživljavati u vlažnim medijima kao što su gram-negativne bakterije, mikroorganizmi koji koloniziraju kožu, oni koji imaju sposobnost adherencije na medicinske uređaje, te mikroorganizmi rezistentni na uobičajene antibiotike. Stoga je čišćenje i dezinfekcija prostora intenzivne njege od velikog značaja u prevenciji i kontroli bolničkih infekcija.

Cilj: Cilj ovog rada je prikazati rezultate evaluacije djelotvornosti aparata za dezinfekciju prostora „Sterisafe Pro“.

Materijal i metode: Demonstracija uređaja izvršena je na odjelu intenzivne njege, $u$ izolacionoj sobi nakon otpusta pacijenta koloniziranog sa bolničkim sojevima bakterija. Prvo uzorkovanje izvršeno je odmah nakon otpusta, drugo nakon standardnog mehaničkog čišćenja opreme i prostora, a treće nakon ciklusa dezinfekcije uređajem,Sterisafe Pro“. Analiza uzetih briseva rađena je u OJ Klinička mikrobiologija. Rađena je kvantitativna metoda obrade uzorka u skladu sa standardnom operativnom procedurom (SOP). Rezultati analiza su izraženi u vrijednostima $\mathrm{CFU} / \mathrm{cm}^{2}$. Rezultati:U brisevima uzetim nakon otpusta pacijenta i mehaničkog čišćenja prostora izolovan je Acinetobacter baumannii u tri uzorka, koagulaza negativni stafilokok u jednom, dok su dva brisa ostala sterilna. U tri uzorka su dokazani Acinetobacter baumannii i koagulaza negativni stafilokok zajedno. Nakon korištenja aparata za dezinfekciju prostora svi brisevi su ostali sterilni.

Zaključak: Dezinfekija prostora uz pomoć aparata,Sterisafe Pro“pokazala se veoma uspješnom. Prednost korištenja aparata je u tome što se ne koriste hemikalije, niski su troškovi rada i upotrebe, bezopasan je za pacijente i osoblje i veoma je jednostavan za upotrebu.

Ključne riječi: dezinfekcija, intenzivna njega, kontrola sterilnosti 


\section{REFERENCES}

1. Dencer SJ. Controlling Hospital-Acquired Infection: Focus on the Role of theEnvironment and New Technologies for Decontamination. Clinical Microbiology Reviews 2014; 27: 46656901.

2. Weber D J, Anderson D, Rutala WA. The Role of the Surface Environment in HealthcareAssociated Infections, Curr Opin Infect Dis 2013; 26 (4): 338-344.

3. Boyce J. Environmental contamination makes a significant contribution tohospital infection, J Hosp. Microbiol., 2007; 65: 50-54.

4. Ropac D. Epidemiology of Infectious Diseases, Medical Publishing, Zagreb, 2003:406- 435.

5. Kalenić S, Budimir A, Bošnjak Z. Guidelines for Hand Hygiene in Health Care Facilities. Medical J 2011: 133 (5-6): 155-170.

6. Damani N. Manual on Prevention and Control of Infections, Third Edition, Medical Publishing, Zagreb, 2015: 26, 58, 77, 80, 81, 135-140, 147, 150.

7. Chemaly RF, Simmons S, Dale C. The role of the healthcare environment in the spread of multidrug-resistant organisms: update on current best practices for containment. Ther Adv Infect Dis 2014; 2 (3-4): 79-90.

8. Huslage K, Rutala WA, Gergen MF. Microbial Assessment of High, Medium, and Low Touch Hospital Rooms. Infect Control Hosp Epidemiol 2013; 34: 211-212.

9. RussottoV, Cortegiani A, Raineri SM, Turning A. Bacterial contamination of inanimate surfaces and equipment in intensive care unit, J Intensive Care 2015; 3:54.

10. Pilipović Lj. Transplantation of pathogen through surfaces in hospital departments and its prevention. Graduate thesis. University of Zagreb, Faculty of Medicine. Zagreb, 2016:23.

Scan this QR code with your mobile device for instant access to the current Issue of Acta Medica Saliniana

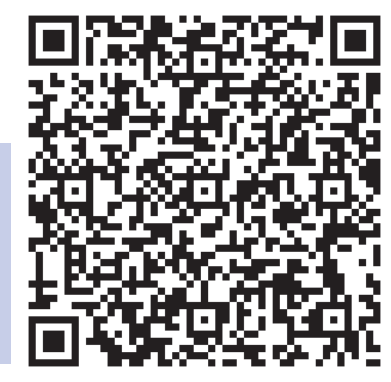

